\title{
DYNAMIC MODELLING AND DESIGN OF FREE WATER SURFACE CONSTRUCTED WETLAND SYSTEMS
}

\author{
GALANOPOULOS C. ${ }^{1}$ \\ LYBERATOS G. ${ }^{2, *}$
}

\author{
${ }^{1}$ Department of Chemical Engineering, University of Patras \\ Caratheodory 1, University Campus, GR 265 04, Patras, Greece \\ ${ }^{2}$ School of Chemical Engineering, National Technical University of Athens \\ Zografou Campus, GR 157 80, Athens, Greece
}

Received: $16 / 09 / 2015$

Accepted: $23 / 03 / 2016$

Available online: $22 / 04 / 2016$ *to whom all correspondence should be addressed: e-mail: lyberatos@chemeng.ntua.gr

\section{ABSTRACT}

A dynamic mathematical model, based on the biochemical kinetic processes dominated in shallow free water systems was developed following the Activated Sludge Model (ASM) methodology. The model predicts plant mass and water uptake rate, $\mathrm{BOD}_{5}$ and total nitrogen (TN) removal on a year round basis, given climatic data (temperature and rain variation). The model was developed based on the operation of two parallel pilot-plant basins, one with plants and one without. The dynamic model was used for the design of full scale constructed wetland facilities for given effluent quality requirements (average annual values of $25 \mathrm{mg} \mathrm{l}^{-1} \mathrm{BOD}_{5}$ and $15 \mathrm{mg} \mathrm{l}^{-1} \mathrm{TN}$ ). It is demonstrated that given inflow information, climatic data and effluent requirements, the required surface area to achieve adequate treatment while securing treated water effluent throughout the year can be determined. In addition, the required initial planting and the amount of plant mass that needs to be cropped on an annual basis is determined. It is also demonstrated that given a total wetland surface, the system performance is optimized if the wetland is divided into two sequential basins, the first with and the second without plants.

Keywords: full-scale design; organics and nitrogen removal; free water surface; constructed wetland

\section{Introduction}

Constructed wetlands have been utilized to treat municipal, agricultural and industrial wastewaters (Knight et al., 1999; Haberl et al., 2003; Babatunde et al., 2009). As described in the study of Vymazal, (2007) frequently low percentages of total nitrogen removal are observed in free water surface wetland systems. A recent review by Wu et al., (2014) mentions the necessity for the development of new optimal designs aiming at securing nitrogen removal.

A model-based method of designing full-scale free water surface constructed wetland systems can secure a satisfactory removal of both organics and nitrogen from a wastewater. The USEPA, (2000) has emphasized the need for the development of appropriate methods are based on the framework of the Activated Sludge Model (ASM) by Henze et al., (1987) adapted for free water surface (FWS) constructed wetlands. Given key input data (climatic data, wastewater quantitative and qualitative characteristics and effluent requirements) the required dimensions of the wetland and the required annual plant harvesting can be determined. This model structure had been used by Nasr and Ismail (2015) to improve the water quality in "Bahr El-Baqar" full-scale drain system on the north-eastern edge of the Nile Delta, receiving a mixture of urban and agricultural discharges. Their simulated results are very satisfactory when using a free water surface system for the organic removal and nitrogen transformation. 


\section{Methods}

\subsection{Dynamic modelling for FWS constructed wetland}

The model was based on pilot-scale experiments as shown in Figure 1. It considered Typha Latifolia as the special vegetation type as described in Kotti et al., (2010) and was fitted by Galanopoulos et al., (2013) using the model software AQUASIM (Reichert, 1998). The pilot systems inflow and outflow characteristics for an annual period (from October 2010 to September 2011) are presented in Table 1.

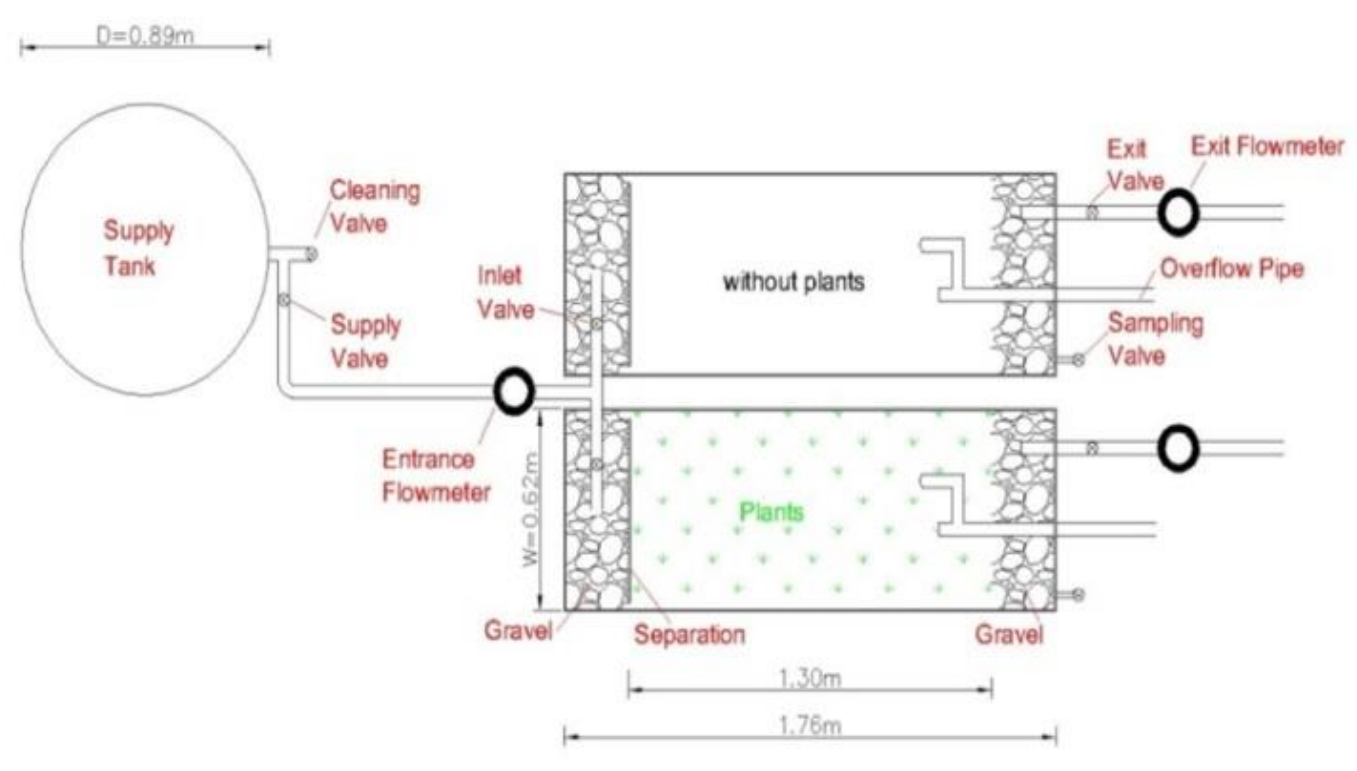

Figure 1. Top view of the identical pilot systems, one planted with Typha Latifolia, the other without

Table 1. Pilot systems inflow and outflow values with their standard deviations.

\begin{tabular}{|c|c|c|c|}
\hline Parameter & $\begin{array}{l}\text { Average inflow } \\
\text { sewage values }\end{array}$ & $\begin{array}{l}\text { Average outflow values } \\
\text { without plants }\end{array}$ & $\begin{array}{c}\text { Average outflow } \\
\text { values with Plants }\end{array}$ \\
\hline $\mathrm{pH}$ & $7.69 \pm 0.26$ & $8.44 \pm 0.42$ & $7.69 \pm 0.15$ \\
\hline $\begin{array}{c}\text { Dissolved Oxygen } \\
{\left[\mathrm{mg} \mathrm{O}_{2} \mathrm{I}^{-1}\right]}\end{array}$ & - & $9.8 \pm 4.3$ & $4.0 \pm 1.9$ \\
\hline $\begin{array}{c}\text { Ammonium Nitrogen } \\
{\left[\mathrm{mg} \mathrm{N} \mathrm{I}^{-1}\right]}\end{array}$ & $16.7 \pm 3.0$ & $2.3 \pm 3.0$ & $2.5 \pm 2.6$ \\
\hline $\begin{array}{c}\text { Nitrate Nitrogen } \\
{\left[\mathrm{mg} \mathrm{N} \mathrm{I}^{-1}\right]}\end{array}$ & $1.0 \pm 0.6$ & $2.6 \pm 1.3$ & $2.3 \pm 1.2$ \\
\hline $\begin{array}{c}\text { Total Kjeldahl } \\
\text { Nitrogen [mg N I-1] }\end{array}$ & $23.0 \pm 5.2$ & $7.8 \pm 2.7$ & $5.7 \pm 2.7$ \\
\hline $\begin{array}{c}\text { Organic Nitrogen } \\
{\left[\mathrm{mg} \mathrm{N} \mathrm{I}^{-1}\right]}\end{array}$ & $7.0 \pm 4.6$ & $5.4 \pm 1.8$ & $3.2 \pm 1.6$ \\
\hline $\mathrm{BOD}\left[\mathrm{mg} \mathrm{BOD} \mathrm{I}^{-1}\right]$ & $108 \pm 28$ & $22 \pm 5$ & $13 \pm 10$ \\
\hline COD [mg COD I-1] & $176 \pm 41$ & $105 \pm 47$ & $36 \pm 22$ \\
\hline
\end{tabular}

The literature values of the model parameters by Galanopoulos et al. (2013) are given in Table 2. The key model variables are the heterotrophic biomass $X_{H}$, the autotrophic biomass $X_{A}$, the algal biomass $X_{A \mid g}$, the organic concentration $S_{S}$, the nitrate nitrogen concentration $S_{N O}$, the ammonium nitrogen concentration $\mathrm{S}_{\mathrm{NH}}$, the organic nitrogen concentration $\mathrm{S}_{\mathrm{Ns}}$ and the plant mass $\mathrm{m}_{\mathrm{p}}$ [g_plants] as shown in Table 3 . The maximum specific growth rates of the various species $\left(m_{H}, m_{A}\right.$ and $\left.m_{A I g}\right)$ are expressed as functions of the water temperature $T_{w}$ as also shown in Table 3. The dimensionless temperature coefficients $\theta$ are considered different above and below $15{ }^{\circ} \mathrm{C}$ following Mara, (1975). The key processes of the dynamic 
model are presented in Table 3 and the stoichiometric coefficients for each process are given in Table 4. The model was then extended (Galanopoulos et al., 2014) to account explicitly for plant growth and water uptake. The plant uptake rate $Q_{\text {plants }}\left[\mathrm{d} \mathrm{d}^{-1}\right]$ depends on air temperature and on the plant mass $m_{p}$ and the plant growth is assumed to be proportional to the nitrogen uptake rate, as shown in Table 3 . Time is denoted as $\mathrm{t}[\mathrm{d}], \theta_{\mathrm{p}}$ is a dimensionless temperature coefficient, $\mathrm{T}_{\mathrm{a}}\left[{ }^{\circ} \mathrm{C}\right]$ air temperature, $\alpha\left[\mathrm{l} /\left(\mathrm{g} \_\right.\right.$plants.d)] is a constant (a reference evapotranspiration rate per plant mass at $10{ }^{\circ} \mathrm{C}$ ), $\mathrm{C}_{\mathrm{N}}\left[\mathrm{mg} \mathrm{N}^{-1}\right]$ is the total nitrogen concentration and $b$ [g_plants $/ \mathrm{mgN}$ ] is the yield of plant mass per total nitrogen taken up. The value of the parameter $b$ was determined to be $0.3 \mathrm{~g}$ _plants $/ \mathrm{mgN}$. The parameters $\theta_{\mathrm{p}}$ and $\alpha$ were 1.1612 and $0.000128 \mathrm{l} /$ (g_plants.d)] respectively.

Table 2. Literature values of model parameters

\begin{tabular}{cccc}
\hline Description & Symbol & Units & Literature values \\
\hline constant saturation substrate heterotrophic biomass & $\mathrm{K}_{\mathrm{s}}$ & $\mathrm{mg} \mathrm{BOD}_{5} \mathrm{I}^{-1}$ & $25-100$ \\
\hline constant saturation ammonium heterotrophic biomass & $\mathrm{K}_{\mathrm{NHN}}$ & $\mathrm{mg} \mathrm{N} \mathrm{I}^{-1}$ & 0.01 \\
\hline constant saturation ammonium nitrification & $\mathrm{K}_{\mathrm{NH}}$ & $\mathrm{mgN} \mathrm{I}^{-1}$ & $0.2-2$ \\
\hline constant saturation ammonification & $\mathrm{K}_{\mathrm{a}}$ & $\mathrm{I} /(\mathrm{mgCOD} \cdot \mathrm{d})$ & $0.00016-0.7$ \\
\hline yield factor in heterotrophic biomass & $\mathrm{Y}_{\mathrm{H}}$ & $\mathrm{mgVSS} / \mathrm{mgBOD}$ & 0.45 \\
\hline yield factor in autotrophic biomass & $\mathrm{Y}_{\mathrm{A}}$ & $\mathrm{mgCOD} / \mathrm{mgN}$ & 0.24 \\
\hline yield factor of nitrogen in algae & $\mathrm{Y}_{\mathrm{Alg}}$ & $\mathrm{mgN} / \mathrm{mgCOD}$ & 0.093 \\
\hline yield factor of nitrogen content in biomass & $\mathrm{Y}_{\mathrm{N}}$ & $\mathrm{mgN} / \mathrm{mgCOD}^{-1}$ & $0.07-0.086$ \\
\hline constant maximum specific rate heterotrophic biomass & $\mathrm{K}_{20}$ & $\mathrm{~d}^{-1}$ & $0.0057-1$ \\
\hline dimensionless temperature $\left(\mathrm{T}>15^{\circ} \mathrm{C}\right)$ coefficient heter. biomass & $\theta_{1}$ & dimensionless & $1-1.135$ \\
\hline dimensionless temperature $\left(\mathrm{T}<15^{\circ} \mathrm{C}\right)$ coefficient heter. biomass & $\theta_{2}$ & dimensionless & $1-1.135$ \\
\hline constant maximum specific rate autotrophic biomass & $\mathrm{K}_{15}$ & $\mathrm{~d}^{-1}$ & $0.01-0.47$ \\
\hline dimensionless temperature $\left(\mathrm{T}>15^{\circ} \mathrm{C}\right)$ coefficient autotr. biomass & $\theta_{\mathrm{N} 1}$ & dimensionless & $1-1.12$ \\
\hline dimensionless temperature $\left(\mathrm{T}<15^{\circ} \mathrm{C}\right)$ coefficient autotr. biomass & $\theta_{\mathrm{N} 2}$ & dimensionless & $1-1.12$ \\
\hline dimensionless temperature $\left(\mathrm{T}>15^{\circ} \mathrm{C}\right)$ coefficient algal growth & $\theta_{\mathrm{Alg} 1}$ & dimensionless & $1-1.12$ \\
\hline dimensionless temperature $\left(\mathrm{T}<15^{\circ} \mathrm{C}\right)$ coefficient algal growth & $\theta_{\mathrm{Alg} 2}$ & dimensionless & $1-1.12$ \\
\hline constant maximum $\mathrm{specific}$ rate algal growth & $\mathrm{K}_{\mathrm{Alg}}$ & $\mathrm{l} /(\mathrm{mgN} \cdot \mathrm{d})$ & $0.01-0.47$ \\
\hline
\end{tabular}

Table 3. Processes and rates

\begin{tabular}{|c|c|c|}
\hline No & Process & Process rate \\
\hline j1 & aerobic growth of heterotrophic bacteria & $\begin{array}{c}\mathrm{m}_{\mathrm{H}} \cdot \mathrm{S}_{\mathrm{S}} /\left(\mathrm{K}_{\mathrm{S}}+\mathrm{S}_{\mathrm{S}}\right) \cdot \mathrm{S}_{\mathrm{NH}} /\left(\mathrm{K}_{\mathrm{NHN}}+\mathrm{S}_{\mathrm{NH}}\right) \cdot \mathrm{X}_{\mathrm{H}} \\
\text { where } \mathrm{m}_{\mathrm{H}}=\mathrm{K}_{20} \cdot \theta^{(\mathrm{TW}-20)}\end{array}$ \\
\hline j2 & Ammonification of organic nitrogen & $\mathrm{K}_{\mathrm{a}} \cdot \mathrm{S}_{\mathrm{NS}} \cdot \mathrm{X}_{\mathrm{H}}$ \\
\hline j3 & aerobic growth of autotrophic bacteria & $\begin{array}{c}\mathrm{m}_{\mathrm{A}} \cdot \mathrm{S}_{\mathrm{NH}} /\left(\mathrm{K}_{\mathrm{NH}}+\mathrm{S}_{\mathrm{NH}}\right) \cdot \mathrm{S}_{\mathrm{O}} /\left(\mathrm{K}_{\mathrm{OA}}+\mathrm{S}_{\mathrm{O}}\right) \cdot \mathrm{X}_{\mathrm{A}} \\
\text { where } \mathrm{m}_{\mathrm{A}}=\mathrm{K}_{15} \cdot \theta_{\mathrm{N}}(\mathrm{Tw}-15)\end{array}$ \\
\hline j4 & algal growth & $\begin{array}{c}\mathrm{m}_{\mathrm{Alg}} \cdot \mathrm{S}_{\mathrm{NO}} \cdot \mathrm{X}_{\mathrm{Alg}} \\
\text { where } \mathrm{m}_{\mathrm{Alg}}=\mathrm{K}_{\mathrm{Alg}} \cdot \theta_{\mathrm{Alg}}(\mathrm{TW}-15)\end{array}$ \\
\hline j5 & plant growth & $\begin{array}{c}\frac{d m_{p}}{d t}=b \cdot Q_{\text {plants }} \cdot C_{N} \\
\text { where } Q_{\text {plants }}=a \cdot \theta_{p}^{\left({ }^{(T a-10)}\right.} \cdot m_{p}\end{array}$ \\
\hline
\end{tabular}

A full-scale FWS validation showed the need to account for oxygen limitation of the nitrification rate in virtue of the low concentrations of the dissolved oxygen, according to Wu et al. (2001). The annual water temperature profile, is determined following by the energy balance equation:

$$
T_{i}-T_{w}=\frac{\left(T_{a}-T_{w}\right) \cdot f \cdot A}{Q_{\text {in }}}
$$

where $\mathrm{f}$ is a transport coefficient with a typical value of $0.5 \mathrm{~m} \mathrm{~d}^{-1}, A\left[\mathrm{~m}^{2}\right]$ is the wetland basin surface, $Q_{\text {in }}$ $\left[\mathrm{m}^{3} \mathrm{~d}^{-1}\right]$ the influent flow rate and $T_{i}$ the inlet water temperature (sewage temperature) with a representative literature value of $15.6^{\circ} \mathrm{C}$. The limitation was accounted for by multiplying the nitrification 
rate by a factor $\left(\mathrm{S}_{\mathrm{O}} / \mathrm{K}_{\mathrm{OA}}+\mathrm{S}_{\mathrm{O}}\right)$ as shown by equation $\mathrm{j} 3$ in Table 3 , where $\mathrm{S}_{\mathrm{o}}$ is the dissolved oxygen concentration (average annual value was $1 \mathrm{mg} \mathrm{l}^{-1}$ as measured) and $\mathrm{K}_{\mathrm{OA}}$ the saturation constant for oxygen taken $0.7 \mathrm{mg} \mathrm{l}^{-1}$ by Rittmann and McCarty (2001). The final model parameter values are given in Table 5.

\subsection{Full-scale design for FWS constructed wetland}

The plant rate $Q_{\text {plants }}$ is the significant factor which depends on the plant mass. When the initial vegetation is too large, the plant mass is greatly increased in the summer months, leading to a very high evapotranspiration rate. The net outflow rate $\mathrm{E}\left[\mathrm{Id}^{-1}\right]$ given by the water balance:

$E=Q_{\text {in }}+$ Rain $-Q_{\text {plants }}$

may then become zero or even negative in these months leading to depletion of the liquid volume of the wetland basin. This fact then imposes an upper limit on the vegetation that needs to be present initially, and determines the amount of annual harvesting that is required to secure stable operation.

Table 4. Stoichiometric coefficients (variable $\rightarrow \mathbf{i}$ and $\mathbf{j} \rightarrow$ process).

\begin{tabular}{|c|c|c|c|c|c|c|c|c|}
\hline No & & $\begin{array}{l}X_{H} \\
\text { i1 }\end{array}$ & $\begin{array}{l}X_{A} \\
\text { i2 }\end{array}$ & $\begin{array}{c}X_{\text {Alg }} \\
\text { i3 }\end{array}$ & $\begin{array}{l}\text { Ss } \\
\text { i4 }\end{array}$ & $\begin{array}{c}\mathrm{S}_{\mathrm{NO}} \\
\text { i5 }\end{array}$ & $\begin{array}{c}\mathrm{S}_{\mathrm{NH}} \\
\mathrm{i} 6\end{array}$ & $\begin{array}{l}\text { SNS } \\
\text { i7 }\end{array}$ \\
\hline j1 & aerobic growth heterot. bacteria & 1 & & & $-1 / Y_{H}$ & & $-Y_{N}$ & \\
\hline j2 & ammonification organic nitrogen & & & & & & 1 & -1 \\
\hline j3 & aerobic growth autot. bacteria & & 1 & & & $1 / Y_{A}$ & $-Y_{N}-1 / Y_{A}$ & \\
\hline j4 & algal growth & & & 1 & & $-Y_{\text {Alg }}$ & & \\
\hline
\end{tabular}

Assuming no vegetation, the required surface $A$ that will ensure the effluent quality of organic charge $\left(B_{0} D_{5}\right)$ and/or total nitrogen (TN) with the annual average value as accepted, according to EU directive $1991 / 271 /$ EEC may be determined. The year-round average effluent quality $x_{a v}$ of any parameter $x$ is determined using the equation:

$\mathrm{x}_{\mathrm{av}}=\frac{1}{\mathrm{n}} \int_{0}^{365} \mathrm{x} \cdot \mathrm{dt}$

Table 5. Model parameter values

\begin{tabular}{|c|c|c|c|c|c|}
\hline Symbol & Units & $\begin{array}{c}\text { Model parameter } \\
\text { value }\end{array}$ & Symbol & Units & $\begin{array}{c}\text { Model parameter } \\
\text { value }\end{array}$ \\
\hline $\mathrm{K}_{\mathrm{S}}$ & $\left.\mathrm{mgBOD}_{5}\right|^{-1}$ & 99 & $\mathrm{~K}_{15}$ & $\mathrm{~d}^{-1}$ & 0.0486 \\
\hline $\mathrm{K}_{\mathrm{NHN}}$ & $\mathrm{mg} \mathrm{N} \mathrm{I}^{-1}$ & 0.01 & $\theta_{\mathrm{N} 1}$ & - & 1.1130 \\
\hline $\mathrm{K}_{\mathrm{NH}}$ & $\mathrm{mg} \mathrm{N} \mathrm{I}^{-1}$ & 1 & $\theta_{\mathrm{N} 2}$ & - & 1.0129 \\
\hline $\mathrm{K}_{\mathrm{a}}$ & $\mathrm{I} /(\mathrm{mgCOD} \cdot \mathrm{d})$ & 0.00016 & $\theta_{\text {Alg1 }}$ & - & 1.0059 \\
\hline $\mathrm{Y}_{\mathrm{H}}$ & $\mathrm{mgVSS} / \mathrm{mgBOD}$ & 0.450 & $\theta_{\text {Alg2 }}$ & - & 1.0960 \\
\hline $\mathrm{Y}_{\mathrm{A}}$ & $\mathrm{mgCOD} / \mathrm{mgN}$ & 0.240 & $\mathrm{~K}_{\mathrm{Alg}}$ & $\mathrm{l} /(\mathrm{mgN} \cdot \mathrm{d})$ & 0.0167 \\
\hline $\mathrm{Y}_{\mathrm{Alg}}$ & $\mathrm{mgN} / \mathrm{mgCOD}$ & 0.093 & So & $\mathrm{mg} \mathrm{O}_{2} \mathrm{l}^{-1}$ & 1.0 \\
\hline $\mathrm{Y}_{\mathrm{N}}$ & $\mathrm{mgN} / \mathrm{mgCOD}$ & 0.071 & $\mathrm{~K}_{\mathrm{OA}}$ & $\mathrm{mg} \mathrm{O}_{2} \mathrm{l}^{-1}$ & 0.7 \\
\hline $\mathrm{K}_{20}$ & $\mathrm{~d}^{-1}$ & 0.2130 & $a$ & I/(g_plants·d) & 0.000128 \\
\hline$\theta_{1}$ & - & 1.0101 & $b$ & g_plants/mgN & 0.3 \\
\hline$\theta_{2}$ & - & 1.0143 & $\theta_{p}$ & - & 1.1612 \\
\hline
\end{tabular}

The design problem then is the following:

Given: (a) wastewater inflow characteristics (flow rate, organics and total nitrogen), (b) Climatic data, i.e. year-round mean daily air temperature and average monthly rainfall rate, (c) Effluent requirements for organics and total nitrogen and (d) An assumed water depth, determine the required surface area to achieve the effluent requirements, the initial plant mass and the required annual plant harvesting. 


\section{Results and discussion}

\subsection{Basin surface determination for a FWS wetland system}

Consider the design of a wetland for a small city of population 400 . Assuming a wastewater production of $120\left[\mathrm{l} /\right.$ (person.d)], the inlet charge $Q_{\text {in }}$ for the plant design is 48,000 [l d $\left.\mathrm{d}^{-1}\right]$. Also, an organic loading of 60 $[\mathrm{g} /$ (person.d)] and a total nitrogen loading of 12 [g/(person.d)] are assumed (Metcalf and Eddy (2003)). Then, the influent organics concentration is $0.5\left[\mathrm{gBOD}_{5} \mathrm{l}^{-1}\right]$, whereas the total nitrogen concentration is $0.1\left[\mathrm{~g} \mathrm{~N} \mathrm{l}^{-1}\right]$, of which $0.06\left[\mathrm{~g} \mathrm{~N} \mathrm{I}^{-1}\right]$ is ammonium nitrogen and $0.04\left[\mathrm{~g} \mathrm{~N} \mathrm{I}^{-1}\right]$ organic nitrogen.

The rainfall data (average monthly values) in [ $\left.\mathrm{mm} \mathrm{d}^{-1}\right]$ (Rio, Patras for the years 2010, 2011 and 2012) have been fitted by a $3^{\text {rd }}$ degree polynomial for $\left.Q_{\text {rain }}\left[1 \mathrm{~d}^{-1} \cdot \mathrm{m}^{-2}\right)\right]$ with $\mathrm{t}$ in $\mathrm{d}$, which was used in the Eq. (2) as Rain $=Q_{\text {rain }} \times A$ :

$$
Q_{\text {rain }}=1.512 \mathrm{e}-0.7 \mathrm{t}^{3}+4.611 \mathrm{e}-0.5 \mathrm{t}^{2}-.033362 \mathrm{t}+4.2115
$$

Average monthly air temperature data $T_{a}$ were determined to give the following $3^{\text {rd }}$ degree polynomial $\mathrm{T}_{\mathrm{a} \_ \text {polyn }}$ at $\left[{ }^{\circ} \mathrm{C}\right]$ for time $\mathrm{t}$ [days] was used in Eq. (1):

$$
\mathrm{T}_{a_{\text {_polyn }}}=-2.1618 \mathrm{e}-0.6 \cdot \mathrm{t}^{3}+0.00067924 \cdot \mathrm{t}^{2}+0.032439 \cdot \mathrm{t}+8.8246
$$

The depth level of the water in the wetland basin is assumed to be regulated at $0.35 \mathrm{~m}$, which implies that the total basin volume is $A \mathrm{~m}^{2} \times 0.35 \mathrm{~m}=0.35 \mathrm{~A} \mathrm{~m}^{3}$. The model application requires an estimate of the water temperature $T_{w}\left[{ }^{\circ} \mathrm{C}\right]$ of the wetland through the Eq. (1), and to this end, the polynomial $T_{a}$ polyn (Eq. (5)). The presence or absence of plants in a basin does not have an impact on the required surface area to achieve a desired effluent concentration. It only influences the water outflow rate from the basin. Assuming no plants in the basin, the model may then be used to determine the effluent concentrations of BOD (organic matter) along with the required effluent quality of $\mathrm{BOD}_{5}<25 \mathrm{mg} \mathrm{I}^{-1}$ as a function of basin surface. Satisfactory BOD removal is achieved with a basin surface of at least $A=0.4$ ha. This, however, does not satisfy the required effluent quality of total nitrogen $\mathrm{TN}<15 \mathrm{mg} \mathrm{l}^{-1}$ (Fig.2). When the basin surface is increased to $A=1.2$ ha, then the required total nitrogen TN effluent is accomplished.

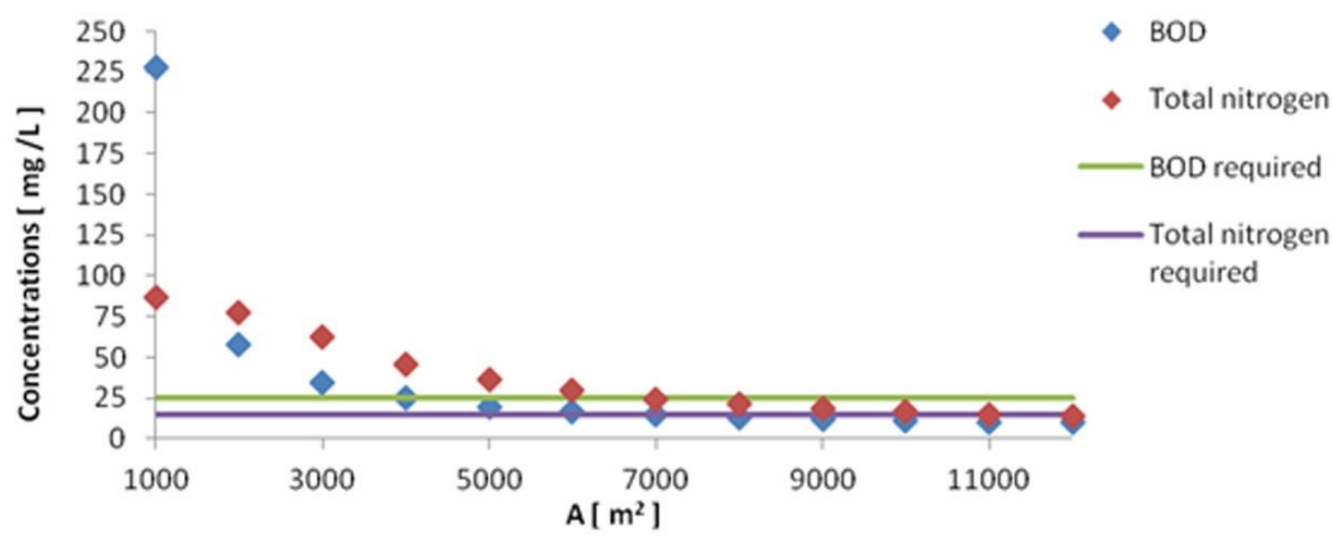

Figure 2. Annual average predicted values of effluent quality for $\mathrm{BOD}_{5}$ and $\mathrm{TN}$ for the basin of one FWS constructed wetland as a function of the basin surface

The presence of vegetation, now, will remove water volume from the wetland basin via water uptake by plants, which grow during the year, leading to a decrease in the outflow rate $E$. The evolution of plant mass $m_{p}$ depends on the initial plant mass $m_{p o}$ [g_plants], and the plant rate $Q_{\text {plants }}$ and the availability of nitrogen nutrients $C_{N}$ as predicted by equations $j 5$ in Table 3. A maximum initial plant mass $m_{\text {po_max }}$ of 3,380,340 g_plants is then determined in order to have nonnegative $E$.

For the case of $A=0.4$ ha for a free water surface wetland basin, in which the outflow rate value is marginally close to zero at a particular point during the summer, the various flow rates are shown in 
Figure 3. It is worth noting that the total mass plant growth during the year reaches 64.06 tn_plants. If from the previous amount of vegetation the moisture percentage $77.10 \%$ for Typha Latifolia by Boyd (1968) is subtracted, the dry total plant mass per year is 36.67 tn_plants/ha. For the biggest aquatic plants it ranges from 4.3 tn_plants/ha to 22.5 tn_plants/ha and a typical dry plant mass of 15.3 tn_plants/ha according to Mitchell (1974).

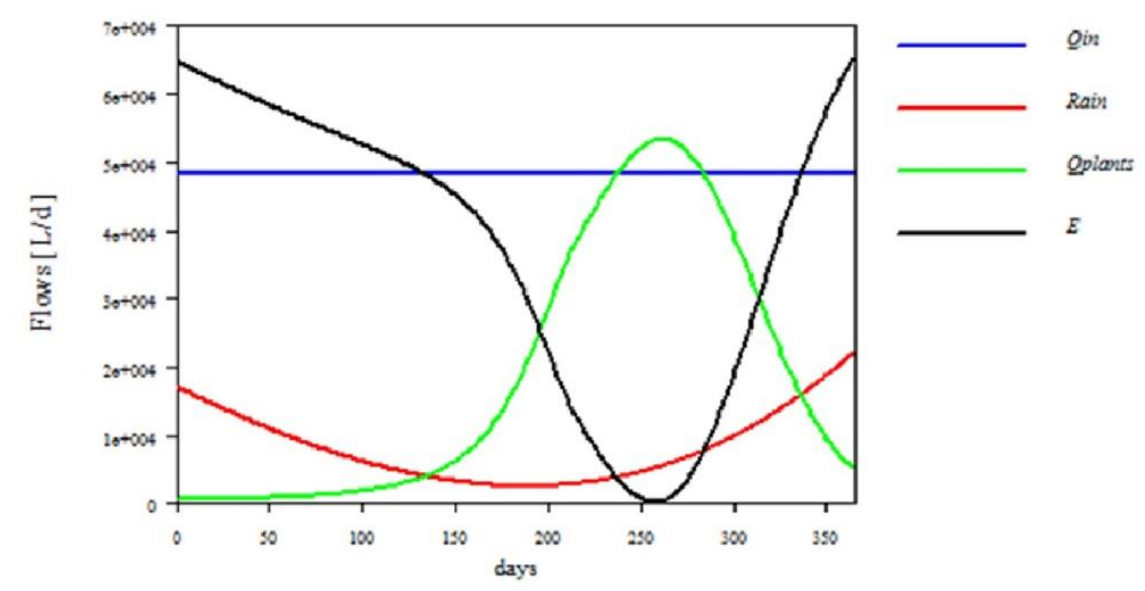

Figure 3. Year-round flow rate estimations of a FWS constructed wetland ( $E$ stands for effluent flow rate)

\subsection{Design of FWS wetland basin systems in sequence}

The total required wetland surface to achieve both organics and nitrogen removal may be reduced by employing two basins in sequence. Let us assume that we already have a basin of 0.4 ha surface area which barely meets the BOD but not the nitrogen requirement, and initial plant mass $m_{\text {po_max1 }}=3,380,340$ g_plants (as already determined to secure nonzero effluent thoroughly the year). The water temperature of each basin is assumed to be equal to that of the first basin water temperature $T_{w 1}\left[{ }^{\circ} \mathrm{C}\right]$ (Eq. (1)).

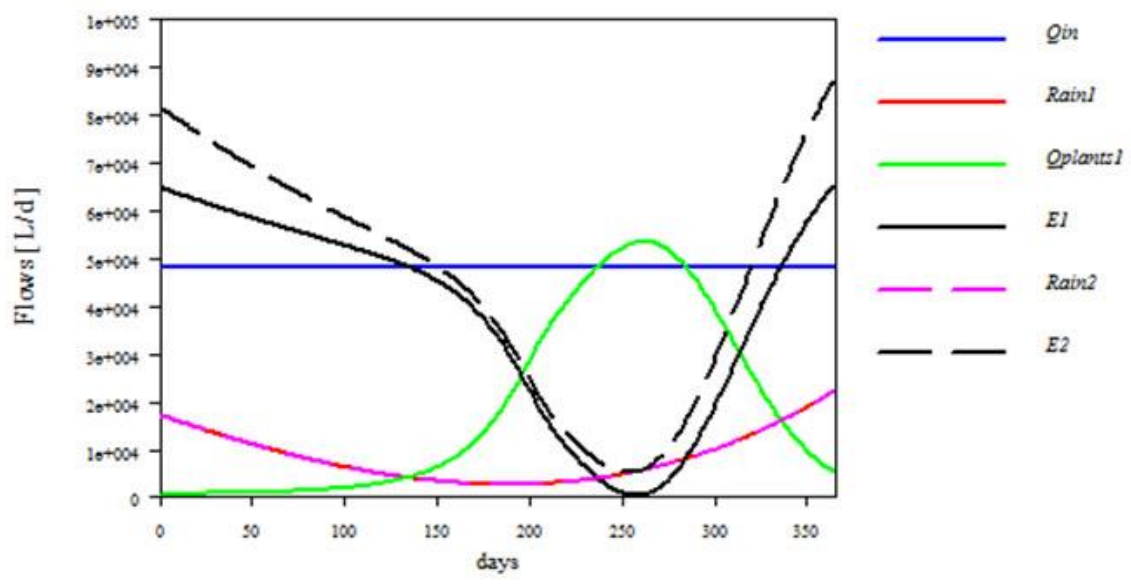

Figure 4. Year-round flow rate estimations of two FWS constructed wetland basins in sequence of a total surface 0.8 ha, the first basin with plants and the second without.

The effluent quality has yearly average values of $\mathrm{BOD}_{5_{-} 1}=25 \mathrm{mg} \mathrm{l}^{-1}$ and $\mathrm{TN}_{-}{ }_{1}=46.0 \mathrm{mg} \mathrm{l}^{-1}$ (Eq. (3)), barely meeting the BOD but not the total nitrogen requirement. In order to avoid a level reduction in the second basin during the summer (negative $E_{2}$ ), the second basin should not be planted at all. For the second basin the oxygen limitation does not need to be taken into account. The estimated effluent quality in terms of total nitrogen of a two-basin in sequence system for various surface areas of the second (not planted) 
basin $A_{2}$ are: $\mathrm{TN}=10.9 \mathrm{mg} \mathrm{l}^{-1}$ for $A_{2}=0.6 \mathrm{ha}, \mathrm{TN}=12.3 \mathrm{mg} \mathrm{l}^{-1}$ for $A_{2}=0.5 \mathrm{ha}, \mathrm{TN}=14.7 \mathrm{mg} \mathrm{l}^{-1}$ for $A_{2}=0.4$ ha and $\mathrm{TN}=16.7 \mathrm{mg} \mathrm{l}^{-1}$ for $A_{2}=0.35$ ha.

So an additional required surface $A_{2}=0.4$ ha is needed to achieve the required effluent quality of total nitrogen ( $\mathrm{TN}<15 \mathrm{mg} \mathrm{l}^{-1}$ ) of the wetland system. It is clear then, that two sequential basins require a smaller total wetland surface ( $0.8 \mathrm{ha}$ ) than a single basin ( $1.2 \mathrm{ha}$ ) for meeting the nitrogen requirement. The flow rates of each basin are depicted in Figure 4.

This then implies that if we had initially a 0.4 ha basin meeting the BOD but not the nitrogen requirement and we need to extend this (retrofit) to achieve also the required nitrogen removal, the best policy is simply to add downstream an unplanted basin of equal size ( $0.4 \mathrm{ha})$.

\section{Conclusions}

The required information for designing a free water surface water basin removing both organic matter and total nitrogen is:

- the annual variation profile of the ambient temperature and rainfall

- the annual profile of the inlet flow rates

- influent wastewater characteristics (organic and nitrogen content)

- the imposed effluent quality in annual average values according to legislation

The design for a wetland basin then includes:

- the determination of the total minimal required surface for achieving the organic and total nitrogen effluent requirements

- the assessment of the initial maximum plant mass required

- the prediction of the plant mass which must be harvested annually

There is a possibility of reducing the total required surface when basins in sequence are used instead. A most suitable wetland system turns out to be two basins in sequence, the first with plants and the second without plants, leading to a reduced total surface requirement. The design of FWS constructed wetlands when both removal of organic and nitrogen charge is demanded is optimized via the dynamic model developed following the Activated Sludge Model framework.

\section{References}

Babatunde O.A., Zhao Q.Y., Burke M.A., Morris A.M. and Hanrahan P.J. (2009), Characterization of aluminium-based water treatment residual for potential phosphororus removal in engineered wetlands, Environmental Pollution, 157, 2830-2836.

Boyd E.C. (1968), Fresh water plants: a potential source of protein, Economic Botany, 22(4), 359-368.

Galanopoulos C., Sazakli E., Leotsinidis M. and Lyberatos G. (2013), A pilot-scale study for modeling a free water surface constructed wetlands wastewater treatment system, Journal of Environmental Chemical Engineering, 1(4), 642-651.

Galanopoulos C., Sazakli E., Leotsinidis M. and Lyberatos G. (2014), Dynamic model extension for the design of fullscale artificial free superficial flow wetland systems, Journal of Environmental Chemical Engineering, 2(4), 2129-2135.

Haberl R., Grego S., Langergraber G., Kadlec R.H., Cicalini A.-R., Dias S.M., Novais J.M., Aubert S., Gerth A., Thomas H. and Hebner A. (2003), Constructed wetlands for the treatment of organic pollutants, Journal of Soils and Sediments, 3(2), 109-124.

Henze M., Grady L.P.C., Gujer W., Marais R.v.G. and Matsuo T. (1987), A general model for single-sludge wastewater treatment systems, Water Research, 21, 505-515. 
Knight R., Kadlec R. and Ohlendorf H. (1999), The use of treatment wetlands for petroleum industry effluents, Environmental Science and Technology, 33(7), 973-980.

Kotti P.I., Gikas D.G. and Tsihrintzis A.V. (2010), Effect of operational and design parameters on removal efficiency of pilot-scale FWS constructed wetlands and comparison with HSF systems, Ecological Engineering, 36, 862-875.

Mara D.D. (1975), Discussion: a note on the design of facultative sewage lagoons, Water Research, 9(5-6), 595-597.

Metcalf \& Eddy, Inc. (2003), Wastewater Engineering: Treatment and Reuse, Fourth Edition, Revised by Tchobanoglous G., Burton L.F. and Stensel D.H. (Ed.), McGraw-Hill, New York, Greek Translation, Thessalonica.

Mitchell D.S. (1974), Aquatic vegetation and its use and control: A contribution to the International Hydrological Decade, Published by UNESCO, Paris.

Nasr M. and Ismail S. (2015), Performance evaluation of sedimentation followed by constructed wetlands for drainage water treatment, Sustainable Environment Research, 25(3), 141-150.

Reichert P. (1998), Computer Program for the Identification and Simulation of Aquatic Systems, AQUASIM 2.0 - User Manual of Swiss Federal Institute for Environmental Science and Technology (EAWAG), Switzerland.

Rittmann B.E. and McCarty P.L. (2001), Environmental Biotechnology: Principles and Applications, McGraw-Hill (International Eds.), Singapore.

USEPA, (2000), Constructed Wetlands Treatment of Municipal Wastewater-Manual, Office of Research and Development, Cincinnati, Ohio. EPA/625/R-99/010.

Vymazal J. (2007), Removal of nutrients in various types of constructed wetlands, Science of The Total Environment, 380(1-3), 48-65.

Wu M.-Y., Franz E.H. and Chen S. (2001), Oxygen fluxes and ammonia removal efficiencies in constructed treatment wetlands, Water Environment Research, 73(6), 661-666.

Wu S., Kuschk P., Brix H., Vymazal J. and Dong R. (2014), Development of constructed wetlands in performance intensifications for wastewater treatment: A nitrogen and organic matter targeted review, Water Research, 57, 40-55. 